\title{
The Way We Play: Male Bodies on a Gay Cruise Website
}

\author{
Diego Santos Vieira de Jesus \\ Correspondence: Diego Santos Vieira de Jesus, holds a Ph.D. in International Relations from PUC-Rio. He is an adjunct \\ professor of Creative Economy and Development at the Superior School of Advertising and Marketing of Rio de \\ Janeiro (ESPM-Rio), Brazil.
}

Received: May 17, 2018

doi:10.11114/smc.v6i1.3299

\author{
Accepted: May 18, 2018 \\ Online Published: May 25, 2018 \\ URL: https://doi.org/10.11114/smc.v6i1.3299
}

\begin{abstract}
The aim is to examine how male bodies are represented on a gay cruise website. The article focus on photographs in which such bodies appear on the official Atlantis Events website in ads for cruises organized by the company for the 2018 season. The central argument points out that the bodies are predominantly masculine and athletic and reproduce aesthetic patterns connected to strength and healthy physical condition, moving away from disparaging stigmas associated with gays and their negative connection to the female condition. The clothes and accessories used by these men and the portrayed situations and places point to a pattern of consumption allowed only to middle and upper class individuals, which ends up marginalizing, in the company's communication, other members of the LGBT population who do not fit into such aesthetic and financial standards.
\end{abstract}

Keywords: body, masculinities, sexualities, publicity, LGBT tourism

\section{Introduction}

Tourism often allows the generation of income and contributes to the development of cities, in the light of its ability to impact other sectors, such as construction and commercial activities. The tourism sector also creates direct and indirect jobs, often with more generating capacity than industrial activities. It increases government tax revenues. After the crisis that hit several tourism companies in 2008 , they have been recovering gradually since the mid-2010, especially the area of sea cruises. During the crisis, this area laid off thousands of workers, mainly in Europe, the United States and Latin America. With the support of governments and service sectors, cruise companies have invested heavily in advertising to recover the number of passengers (Azevedo et. al, 2012; Jesus, 2017).

Specific advertising for segmented audiences can be effective because it has the potential to alleviate crisis effects or even the negative effects of seasonality, seeking to attract audiences who are often not so sensitive to fluctuations. Among these people, one can indicate specifically homosexual men, who, in the LGBT population, represent a relevant portion. Most of these men haver high power consumption and above-average cultural level. High-income gays often represent a demanding segment that seeks to acquire more expensive goods and quality services. The recognition of the potential for consumption of this public has occurred concurrently with the pursuit of respect for the LGBT rights, although in economic and financial terms many members of the LGBT population do not have the same access upper-class gay men have to opportunities (Altaf and Troccoli, 2009).

In the tourism sector, the realization of sea cruises specifically aimed at the gay public was intensified in this decade, particularly after the crisis. Among the companies that stood out in this field, it is worth mentioning Atlantis Events. Established in the early 1990s, the company has become the largest company in the world dedicated to organizing specific trips for the LGBT population - especially gay men - at cruises and resorts. According to the official website of the company, it has a diversified team in terms of experiences and origins, in which cultural producers, administrators and specialists in tourism and customer services work. With the motto "The way we play", the company welcomes around 20,000 guests a year and seeks to create experiences where guests can "be themselves and have fun in ways they never imagined" (Atlantis Events, 2017), according to Atlantis's website. The company also mentions in its website the commitment to offer the highest standards of service to all its guests.

The aim is to examine how male bodies are represented on gay cruise sites. The article focus on the photographs in which such bodies appear on the official Atlantis Events website in ads for cruises organized by the company for the 2018 season. The central argument points out that the bodies are predominantly masculine and athletic, which reproduce aesthetic patterns connected to strength and healthy physical condition, moving away from disparaging stigmas 
associated with gays and their negative connection to the female condition. The clothes and accessories used by these men and the portrayed situations and places point to a pattern of consumption allowed only to middle and upper-class individuals, which ends up marginalizing, in the company's communication, other members of the LGBT population who do not fit into such aesthetic and financial standards.

\section{Theoretical Framework}

According to Foucault (1988), rules - which can be created by the state, the family, the school or the church, for example -, censorship and interdiction are examples of the exercise of control over sex. The pursuit of sexual pleasure with people of the same sex carries with it disobedience to the constitutive law of desire, transgression and joy. The construction of the homosexual man occurs in the exercise of his sexuality and lifestyle, which had as its most recent strategies the public declaration of his sexuality, the defense of existential spaces, the political organization and the conquest of positions in the job market. Such strategies have contributed to a gradual transformation of homosexual visibility into everyday life. As Mendonça (2012) points out, the expansion of visibility gradually emerged from the battle against crystallized beliefs and values and the maturation of these transformations, with a focus on the reordering of dominant symbols that disqualified gays in the public sphere.

Since the nineteenth century, these beliefs and values have been crystallized not only by law, but also by medicine, which sought in the individual's body something that would differentiate homosexuals. The homosexual body classified by medical sciences gained visibility and materiality, which broadened the interests of moral regulation and vigilance over it (Mendonça, 2012). Homosexuals came to be seen as a unique group that shared distinct behavioral patterns, and their bodies began to undergo research to detect their "illness," which typified a group of people and offered them their own identity (Foucault, 1988).

Psychology also sought explanations for deviant sexual behaviors and placed homosexuality as a result of trauma. In this process, the stigmas of the sinner, the criminal, the physically and mentally ill have surrounded homosexuals and fuelled multiple ways of discrimination and prejudice. While homosexuals sought non-verbal communication as a strategy of resistance, heterosexual dominance was reinforced by the mobilization of verbal communication to assert that the dressing, the gestures and the bodily conduct were "symptoms" of homosexuality as a form of repelling it (Mendonça, 2012). So many elements that covered the body and the movements effected by it typified an ideal of masculinity that repelled the association of this ideal with femininity and homosexuality (Gil, 2005). Over time, expressive materials and aesthetic forms of life were mobilized by social actors with the purpose of modifying bodies and personalizing subjects through ethical and aesthetic values in attempts to construct heterosexual masculinity as opposed to homosexuality (Wilson, 2003).

These attempts also went through actions to sanitize social life, which mobilized symbolic violence to impose discipline over the bodies of individuals. The medicalization of homosexuality accompanied the refinement of other techniques of sexual vigilance, which characterized marriage as divine and fidelity as a condition for the survival of the family, and posited that deviant forms of sexuality should be investigated and normalized (Mendonça, 2012). Medical and psychological institutions, governments and churches had classifying discourses around the homosexual body and identity to frame such deviant subjectivities (Featherstone, 1995). While on the one hand legal terms and the medical and psychological sciences instrumentalized symbolic violence towards homosexuals and the knowledge produced on their body operated as a social controller, actions of resistance through literature, the visual arts and much of the media established the boundaries of a common existential territory in which collective experiences of multiple forms of sexual identity were produced. These spaces escaped the vertical domination of power and generated symbolic networks capable of signifying homosexual identities (Villaamil, 2004).

Since the end of the twentieth century, market agents have noticed in the movements of expansion of the spaces of homosociality - at work, in the family and in the media - new fields of action. They realized the purchasing power of a new audience, which made it look for another image of homosexual to be linked to their goods and services. This did not presuppose that market players necessarily embraced the struggle for gay rights, but rather developed strategies in open spaces to capture the public's interest. The association of the gay man to the image of a man who invests in body care and spends much with himself enormously seduced capitalist institutions. In the light of the economic and financial potential of these men, the incorporation of images associated with their lifestyles, the provision of specific services for them and the creation of spaces for leisure and entertainment for this public contributed to greater homosexual visibility, but created the notion of inclusion by consumption and the exclusion of a large part of the LGBT population that did not fit into the profile of middle and upper-class white gay men (Mendonça, 2012).

Gay vanity drives a multimillion-dollar market that ranges from clothing and accessories to tourism and places that have attractions and services for gay men. In this sense, the homosexual body was prepared to live such a life-style offered by capitalism, which reveals that the very construction of desire involved not only the presentation of bodies, but the 
environments in which they participate. In the light of the prejudice reactivated with the increasing association of homosexuality with the spread of HIV and AIDS since the early 1980s, combating the image of a "diseased body" came as a display of a vigorous and healthy body, which strengthened the reconfiguration of these social characters by shaking the existential territories reserved for homosexuals until then (Mendonça, 2012). In the view of many homosexual men, the feminization game only reinforced prejudices toward gays, so they saw the need to appeal to alternative identity markers. In this sense, some gay men assumed an extremely muscular and virile body, whereas the "effeminate ones" felt obliged to present themselves in a masculine form (Tamagne, 2013).

The overexposure of the female image - already denounced by the feminist movement since the 1960s - opened space for the market to increasingly use the male body as an object of seduction. Although initially the Apollonian male body was exploited by advertising and propaganda as a symbol of discipline since the beginning of the twentieth century, the purpose at that time was more educational, with a body that was not so eroticized. However, from the 1980s onwards, advertising was not only about educating about the use of products by mobilizing the male body, but also entertaining the public, so that this body gradually came to be conceived as a pleasure machine for women and even other men. As a machine, this body had an image fit for production and could undergo replacements and correct imperfections - in this case, aesthetic ones (Bocock, 1992).

Being endowed with historicity, the regime of visibility of the male body gradually took place through communicational flows that engender different processes of subjectivation (Hoff, 2016). The first photographs of naked or semi-naked male bodies had scientific purposes, such as to demonstrate the functioning of locomotion. However, by the end of the nineteenth century, a number of photographers - notably Baron von Gloeden and Guglielmo Plüschow - captured bodies of naked men in artistic form, often in interaction with nature. With the emergence of male nude catalogues and the gradually eroticized presence of very masculine men in the cinema - such as Tab Hunter, James Dean and Marlon Brando - the aesthetic pattern of a vigorous, masculine body spread throughout the world, in order to stimulate the cult of the male body in gyms and publications destined to this market. The visual and verbal texts of these magazines often resembled the image of the man portrayed in Renaissance paintings, represented in all its power in the appreciation of parts of his body and the mobilization of phallic symbols that accompany the image. The aesthetic quality of the work of photographers such as Pierre et Gilles and Robert Mapplethorpe made the photographs of nude or semi-naked men considered by critics no longer only elements of interest restricted to feminine and gay desires, but as artistic objects (Mendonça, 2012; Tamagne, 2013).

In the case of advertising, the visibility of the bodies was expressed according to hegemonic configurations, which referred to hierarchies that eliminated human agency - especially women's agency - in ads. Often the reason for the existence of the female body in advertising campaigns was in the eyes of others, so that this body did not constitute subjectivity or identity to the subject, but it was configured as an object that was slavishly accepted by the observer (Silva and Gonçalves, 2017). Since the mid-1990s, various advertising agencies have been devoted to the spread of homosexual lifestyles, more specifically gay men. The investment in advertising for such men was explained not only by considering that goods and services marketed aimed at women already contemplated lesbians. This was also because gay men invested heavily in body care and the consumption of superfluous goods to effect a radical change in terms of regulations on the aesthetic body. Such a body should have the appearance of beauty and care, without extinguishing the image of virility, security and strength, associated with the role of man in society (Mendonça, 2012). In this sense, the "gay macho" could have an aesthetic concern while still being considered a "true man", which came in response to the stigmas that homosexuals were victims of in a heterosexist society. The very term "macho" evokes ideas such as strength and self-confidence. The male body was valued by clothes that marked his muscles and eroticized by the use of accessories whose signification was codified, besides the incorporation of manly postures and gestures. The practice of bodybuilding appeared as an aggressive reaction to the revaluation of the body for a long time perceived as ugly. Such a body was at the same time placed as a strategy of seduction (Tamagne, 2013).

Given the perceived greater purchasing power of homosexual gay men and the social achievements the LGBT population have had in many countries, business has begun to develop increasingly diversified services to meet the needs of gay men and develop the advertising that highlights the body of the gay, white and wealthy man (Trevisan, 2000). For some companies, homosexual men became the focus of commercial action, given that they are often loyal customers to the brands with which they identify themselves, buy the products stimulated more because of quality and style than price and have a greater amount of money to invest in themselves, consuming much of their gains with entertainment and travel (Jesus, 2017). However, in the light of the persistence of conservative traits in various contemporary societies, the movement of some companies towards the demands of homosexual men has fluctuated due to the fear of losing heterosexual consumers and the opportunity to attract new clients (Mendonça, 2012; Tamagne, 2013).

The market often infers a simplifying view of the multiple composition of the gay population, given that it is assumed that the homosexual is seen, regardless of the differences that exist within the population itself, as an individual with 
great consumer potential, good taste and high level of quality and differentiated service requirements (Jesus, 2017). Although the group is marked by heterogeneity, the common traits aggregate many of these people through identification processes, which are based on an aesthetic pattern of dominant consumption (Bourdieu, 1997).

Faced with the development of the so-called "pink capitalism" - focused on the aesthetic and cultural needs of gay, white, western, white and upper and middle-class men (Drucker, 2015) -, an aesthetically idealized image of this man is explored by companies of the tourism sector, that have become pioneers in the attraction and the development of differentiated services to homosexuals. Travel agencies, operators, hotels and car rental companies have shown an interest in attending such a public, even training employees for this specific function (Mendonça, 2012). Although not always concerned with developing social work to raise awareness about LGBT rights, the advertising developed for the sale of tourism services increasingly mobilized the body of homosexual man in ads and campaigns, so to reveal the identification of the company with a demanding public that can pay for expensive and quality services. Often, target areas are sexualized to allow the projection of repressed sexual desires in the very societies in which the man lives, especially when the destination of the journey is a peripheral area of the planet (McClintock, 1995).

In the case of gay cruises, what is usually sold through the websites of the companies that organize such trips are experiences marked by parties in the nightclubs or the open areas of ships at sea, diversified gastronomy, shows with LGBT artists or themes, exhibition of semi-naked bodies in the swimming pools and jacuzzis, stop at ports for walks in sophisticated or exotic places - in which there are usually activities related to gay life, such as parties and LGBT Pride Parades - and the possibility of making friends and having sexual encounters with other gay men. The participants of these cruises also have a highly qualified team specialized in meeting their demands, both on and off the ship. As these men show particularities as purchasers of tourism products, they often promote investments higher than those made by other tourism segments by leaving more financial resources in the ships and the cities which they visit (Azevedo et al., 2012). Thus, the companies that carry out such cruises and ventures in the places which receive tourists are seeking to mobilize strategies of differentiation (Kotler and Keller, 2006) for the attraction, service and loyalty of these men. However, as Churchmuch (2010) argues, the market may even incorporate standards valued by such a public, but it does not necessarily promote engagement to convince that its sympathy to LGBT causes is real.

Market segmentation can bring numerous benefits, such as better understanding of customer needs, more productive business performance, better positioning of the product or service in the market, easier choice of communication channels and more efficient language to communicate with a certain public (Dias, 2005). In the advertising produced for the consumer who decides to participate in gay cruises, the mobilization of the vigorous masculine body proved fundamental, for it often approaches a pattern of beauty that reveals aesthetic perfection, strength and healthy physical condition, moving away from derogatory stigmas connected to gay men and their negative connection to the female condition. Thus, the valorization of the male body is seen as a form of protection in relation to the multiple forms of symbolic and physical violence perpetrated against women and all associated with the feminine (Miskolci, 2016). As Tamagne (2013) puts it, a stereotypical way of life of what is to be "homosexual" is a celebration of a supposed greater sexual liberation, at the same time that the commercialization of a homosexual subculture is developed, which primarily benefits higher income gay men. Far from being liberating, this commodification has generated new exclusions from all those who cannot respond to such aesthetic demands because they are very "effeminate", poor or insufficiently muscular (Tamagne, 2013).

\section{Methodological Considerations}

In the first stage of the research, data were collected on the Atlantis Events website (http://atlantisevents.com/), more specifically in the "Cruises" section, in December 2017. The ads of all the cruises organized by the company for the 2018 season were considered, namely: the Harmony Caribbean Cruise, in January; the Auckland to Sydney Cruise, in February and March; the Exotic Southern Caribbean Cruise, in March; the Rome to Barcelona Cruise, in August; and the Italy \& Greek Isles Cruise, also in August. In the webpages referring to each cruise, I selected the photographs that presented male bodies for the promotion of each trip. In general, such photographs were taken in previous seasons, in the same route in previous years and / or on the same ship. The images discarded in the research often portrayed only the physical ambience of the cities in which ships would stop, maps with cruise itineraries, and accommodations and other ship facilities. Although the texts that accompanied such images brought relevant information about accommodations, services, cities in which ships would stop and prices, the focus of the research turned exclusively to the images, considering that the visual appeal tends to predominate in advertising pieces of gay cruises.

In a second step, I examined each selected photograph to understand more specifically how the male bodies are represented. I used a qualitative approach of document analysis as developed by Glenn Bowen (2009), which requires that data provided by documents - I this case, the selected photographs - be examined and interpreted in order to elicit meaning, gain understanding and develop empirical knowledge. In this study, the purpose was to identify the profile of 
the portrayed male bodies considering the aesthetic elements that compose the image, especially the characterization of the body through its type and clothing and its relation to the places in which it is portrayed. I also developed a bibliographic research to gather data about theoretical and conceptual aspects of the use of male bodies in advertising.

In the light of Bowen's (2009) guidelines, I defined categories which allow a more precise characterization of the male body portrayal in the selected photographs, considering its aesthetics elements and its relations to the environments in which these men were located. According to these guidelines, the elements considered in each image in order to understand male bodies' representations were systematized into three categories: 1) the profile of the male bodies portrayed in terms of their appearance, as well as the clothing and accessories used by such men; 2) their actions in the photos; 3 ) the places where they develop such actions. Considering the categorization of the compiled data, I sought to describe and later interpret the content of the images based on the theoretical-conceptual support, which enables to capture their symbolic, figurative, metaphoric or allegorical meaning (Vergara, 2012).

\section{Results}

\subsection{Bodies, Clothing and Accessories}

In the ads for all cruises, the portrayed male body is predominantly of a 30-50 years old white gay man. The bodies, usually tanned, appear with bare torsos, exhibiting a very strrong musculature and a vigorous and masculine profile, in particular the Italy \& Greek Isles Cruise ad. Few are those bodies that do not appear exhibiting a hypertrophied musculature. All the men portrayed smile and often appear hugging friends or partners in the areas of the ships, especially the external ones (in which pools and jacuzzis are located), or in beaches and historical places of the cities where the ships stop. The images of black or latino men are less frequent, as well as older men, the latter appearing more often in pictures from the Exotic Southern Caribbean Cruise and the Italy \& Greek Isles Cruise ads. However, even those men who appear less exhibit aesthetically muscular bodies, usually with waxed chest and abdomen.

In general, such men wear shorts from internationally renowned brands, beach shorts or bathing suits, as well as costumes at thematic parties. For example, in the Harmony Caribbean Cruise ad, nine muscular men - mostly white appear wearing leggings with green and gray camouflage, in reference to the military party held on the ship during the cruise. In another photo, some appear sitting on the shoulders of friends, suggesting a relationship of intimacy. Other photos show men hugging and posing for the camera with naked torsos in Auckland to Sydney Cruise, Exotic Southern Caribbean Cruise and Italy \& Greek Isles Cruise ads. Most are white and have muscular bodies, especially with little clothing, which allows to see in detail the contours of their muscles. Many of these men wear accessories that reinforce the masculine condition, such as sporting sunglasses.

Some photos value the agglomeration of many men with semi-naked bodies in the external areas of the ship during the parties at the cruises. Most bodies are muscular, white and healthy looking. Some men appear wearing gladiator costumes for Sydney's Mardi Gras, exhibiting the defined musculature of their bodies.

\subsection{The Actions}

In some pictures, such men show affection toward others, such as hugging each other in the pool or walking hand in hand on the beaches of the places where the ships stop, as seen in the Exotic Southern Caribbean Cruise ad. In the Italy \& Greek Isles Cruise ad, some of them appear in a swimwear at the ship's external area, while others toast smiling, shirtless for the camera, in a bar outside the ship.

In other photos of the Auckland to Sydney Cruise and the Exotic Southern Caribbean Cruise ads, white gays mostly show up toasting in elegant restaurants on ships, using more sober clothing. On the second cruise, some appear in modern-design bathing suits, playing on Caribbean beaches, or even leaning on the backs of other men on the beach or by the ship's pool. In this same ad, muscular men appear drinking and dancing in the daytime parties in external areas of the ship. In other photos, they appear wearing wigs and glasses and exhibit their semi-naked bodies. Some make physical contacts with others that suggest intimacy, such as a man who appears holding another's chest in a hug from behind in one of the photos of the Exotic Southern Caribbean Cruise ad.

\subsection{The Places}

The men portrayed in the ads appear semi-naked in the cities in which the ships stop, such as in Sydney's Mardi Gras in the Auckland to Sydney Cruise ad, and on the ship itself, in which flashes of colored lights appear in night-time celebrations, suggestive of a nightclub setting. A similar setting also appears in photos of the Rome to Barcelona Cruise ad, in which men appear dancing and talking at a party at night, with beams and light effects. While on Caribbean cruises and Italy \& Greek Isles Cruise ads, reference to the interaction among these men in the beach environment is frequent, in the Rome to Barcelona Cruise ad, they appear walking and smiling through the historic streets of Barcelona or in front of the Coliseum in Rome, using light clothes such as T-shirts that show their muscles. On this same cruise, some appear wearing bathrobes in the ship's spa looking at the ocean, which suggests relaxation. 


\section{Analysis and Discussion}

If homosexual liberation has allowed more men to live their sexuality more openly, the gay presentation is still negotiated in terms of places and situations for prudence, shame or even opportunism. As can be seen in the appearance of the male bodies and their dressing and accessories in the Atlantis Events cruise ads for the 2018 season, the homosexual male body is presented as predominantly masculine, young, beautiful and vigorous, reflecting, as Tamagne points out (2013), the commodification of a homosexual subculture that focuses primarily on the gay, sectarian consumer and belonging to the wealthier classes. Such a body is embedded in the dynamics of "pink capitalism," as posed by Drucker (2015), and assumes patterns of beauty and care consolidated in this socioeconomic context, but without eliminating the ideas of virility and strength, as Mendonça (2012) argued. In line with the argument posed by Silva and Gonçalves (2017), the body appears predominantly semi-naked, placing itself as an object that is slavishly accepted in the interest of those who observe it - in this case, the high-income gay public who wishes to have this body or use it sexually, identifies with it and assumes that it carries the ideal aesthetic pattern to be followed. The clothes and accessories these men wear show their alignment with the high patterns of consumption defined in the development of "pink capitalism," which reveal their status and prestige in relation to those who do not follow the same standards.

The photos in which these men interact usually bring them hugging or forming groups. It suggests, as Miskolci (2016) argues, that the valorization of the masculine body not only protects them from multiple forms of symbolic and physical violence, but generates relations of intimacy among them. In such interaction, such men play, toast and amuse themselves, as if the situation of exclusion, prejudice and intolerance towards homosexuals prevailing in contemporary society did not reach them. In line with the idea proposed by Jesus (2017), the simplifying version that the market brings of the homosexual removes the negative social connotations associated with gay people and ignores the ones related to the existing differences within the homosexual population. The individuals portrayed seem, in the logic of the ads, to achieve the happiness expressed in the photos from their expanded potential for the consumption of goods and services of good taste, that meet their high level of exigency as to the quality. The dominant aesthetic pattern, according to Bourdieu (1997), aggregates these people around processes of identification. However, as Tamagne (2013) points out, the commercialization of this way of life has moved away from liberating standards of the entire gay population through consumption and has reinforced new parameters of exclusion from those who do not respond to the same aesthetic and consumption requirements.

The sophisticated and differentiated places - such as the cities in which the ships stop - not only make up the scenario in which this idealized way of life in the ads develops, but also help to make such bodies more socially valued. The presence of such men in nightclubs, bars or spas on ships shows not only their preoccupation with entertainment or body care, but they offer spaces in which they can realize their identities associated with consumption or, in the argument posed by McClintock (1995), project desires repressed in everyday life, relaxing the restrictions of everyday life for the full exercise of their desires associated with bodies that approach the aesthetic ideal valued in the market.

\section{Conclusion}

It was possible to perceive that the strategy of differentiation adopted by companies to reach the gay consumer of sea cruises tries to meet their high-standard demands, but, focusing exclusively on a male ideal body in the produced ads, it ends up reproducing stereotypes within the gay population itself (Azevedo et al., 2012). Although homosexual men become the focus of commercial action - particularly because many of them are loyal customers to brands that meet high standards - the quality and lifestyle proposed in the Atlantis Events official website ads are not available to any gay men, but only to those who have more capital to spend on entertainment and travel, as Jesus (2017) argues.

In this sense, the ads that follow this same profile point out that certain goods and services are not accessible to the entire gay population, in order to strengthen aesthetic patterns of consumption that stimulate even more socioeconomic divisions within the LGBT population. Given the changes brought by a number of LGBT groups around the globe so that such internal divisions can be minimized, companies could not only look at the potential of LGBT people who do not fit the white gay man pattern, but for the social commitment of these firms in terms of seeking a fuller engagement with this population and contributing to greater cohesion among these people, regardless of their origins, ethnicity or economic and financial conditions, also stimulating respect to all of those who do not fit heterosexist standards.

\section{References}

Alantis Events (2017). Atlantis Events website. Retrieved from http://atlantisevents.com/

Altaf, J., \& Trocolli, I. R. (2009). Autoconceito e Marcas de Luxo: Associação Aplicada ao Consumidor Homossexual Masculino. XII SEMEAD Anais, Bauru.

Azevedo, M. S., Martins, C. B., \& Kassouf, F. O. E. (2012). Segmentação no setor turístico: o turista LGBT de São Paulo. Revista de Administração da UFSM, 5(3), 493-506. https://doi.org/10.5902/198346593852 
Bocock, R. (1992). Consumption and lifestyles. In.; Thompson, K (Eds.) Social and cultural forms of modernity. (pp.119-167) Oxford: Open University Press.

Bourdieu, P. (1997). La distinction - critique sociale du jugement. Paris: Les Éditions de Minuit.

Bowen, G. (2009). Document analysis as a qualitative research method. Qualitative Research Journal, 9(2), 27-40. https://doi.org/10.3316/QRJ0902027

Churchmuch, T. (2010). Turismo LGBT - Trabalhando diversidades. $5^{\circ}$ Salão do Turismo Anais. São Paulo.

Dias, R. (2005). Introdução ao Turismo. São Paulo: Atlas.

Drucker, P. (2015). Warped: Gay Normality and Queer Anti-Capitalism. Leiden: Brill. https://doi.org/10.1163/9789004288119

Featherstone, M. (1995). Cultura de consumo e pós-modernismo. São Paulo: Studio Nobel.

Foucault, M. (1988). História da sexualidade II: o uso dos prazeres. Rio de Janeiro: Graal.

Gil, J. (2005). Portugal, hoje: o medo de existir. Lisboa: Relógio D’Água.

Hoff, T. (2016). Corpos discursivos: dos regimes de visibilidade às biossociabilidades do consumo. Recife: Editora UFPE.

Jesus, D. S. V. (2017). Só para o moço do corpo dourado do sol de Ipanema: distribuição espacial da economia noturna LGBT na cidade do Rio de Janeiro. Revista Brasileira de Estudos Urbanos e Regionais, 19(2), 288-309. https://doi.org/10.22296/2317-1529.2017v19n2p288

Kotler, P., \& Keller, K. V. (2006). Administração de Marketing. São Paulo: Atlas.

McClintock, A. (1995). Imperial Leather: Race, Gender and Sexuality in the Colonial Contest. New York, London: Routledge.

Mendonça, C. C. (2012). E o verbo se fez homem: corpo e mídia. São Paulo: Intermeios.

Miskolci, R. (2016). Teoria Queer: um aprendizado pelas diferenças. Belo Horizonte: Autêntica.

Silva, T., \& Gonçalves, E. M. (2017). Diversidade de corpos na publicidade: o contexto interpretativo nas campanhas Skolors e Reposter da Skol no Facebook. Tríade, 5(10), 95-112.

Tamagne, F. (2013). Mutações homossexuais. In: Corbin, A., Courtine, J.-J.; Vigarrelo, G. (Eds.) História da Virilidade: A virilidade em crise? Séculos XX-XXI. (pp.424-453). Petrópolis: Vozes.

Trevisan, J. S. (2000). Devassos no paraíso. A homossexualidade no Brasil, da colônia à atualidade. Rio de Janeiro: Record.

Vergara, S. (2012). Métodos de pesquisa em Administração. São Paulo: Atlas.

Villamil, F. (2004). La transformación de la identidad gay en España. Madrid: Catarata.

Wilson, E. (2003). Adorned in dreams: fashion and modernity. New Brunswick: Rutgers University Press.

\section{Copyrights}

Copyright for this article is retained by the author(s), with first publication rights granted to the journal.

This is an open-access article distributed under the terms and conditions of the Creative Commons Attribution license which permits unrestricted use, distribution, and reproduction in any medium, provided the original work is properly cited. 